JaCEK StRojny

Politechnika Rzeszowska, Polska - Rzeszów University of Technology, Poland

Michat ChODOREK

Absolwent Wydziału Zarządzania Politechniki Rzeszowskiej • Poland

\title{
Badanie poziomu przedsiębiorczości indywidualnej na grupie studentów studiów magisterskich Wydziału Zarządzania Politechniki Rzeszowskiej
}

\author{
Examination of the Level of Individual Entrepreneurship within the Group of Graduate \\ Students of the Faculty of Management, University of Rzeszow
}

Streszczenie: Analizując przedsiębiorczość, nie należy kierować się wyłącznie kontekstem związanym z prowadzeniem działalności gospodarczej. Badane zjawisko ma bowiem znacznie bardziej złożony charakter. Jest ono determinowane przez liczne czynniki o charakterze ekonomicznym, prawnym, technologicznym, społeczno-kulturowym. Ponadto ma znacznie szersze przełożenie na procesy społeczne i kulturowe. Przedsiębiorczość rozumiana jako pewien zbiór atrybutów indywidualnych może uzewnętrzniać się w postaci proaktywnych i kreatywnych działań w różnych obszarach życia społecznego. Celem niniejszego artykułu jest ocena poziomu przedsiębiorczości indywidualnej na podstawie badań przeprowadzonych na grupie studentów studiów magisterskich Wydziału Zarządzania Politechniki Rzeszowskiej. W pierwszej jego części scharakteryzowano takie pojęcia, jak: „przedsiębiorczość”, „przedsiębiorczość indywidualna” i „przedsiębiorczość akademicka”. W dalszej części pracy skupiono się na wymiarze indywidualnym przedsiębiorczości. Określono jej główne wymiary i subwymiary (parametry). Tak zoperacjonalizowane pojęcie przedsiębiorczości posłużyło do przygotowania i przeprowadzenia badań w grupie docelowej. Uzyskane wyniki oraz ich podsumowanie przedstawiono w kolejnych częściach artykułu.

\begin{abstract}
An analysis of an entrepreneurship should not be guided absolutely by the context associated with business running. The studied phenomenon is in fact much more complex. It is determined by numerous factors, such as economic, legal, technological, socio-cultural. It also has a much broader impact on the social and cultural processes. Entrepreneurship understood as a set of individual attributes can externalize in the form of proactive and creative activities in various areas of social life.The purpose of this article is to assess the level of individual entrepreneurship, conducted on a group of graduate students of the Faculty of Management University of Rzeszow. The first part characterizes the concept of entrepreneurship, personal entrepreneurship and academic entrepreneurship. The rest of the work focuses on the dimension of personal entrepreneurship. Its main dimensions and sub-dimensions (parameters) are identified there. This, operationalized concept of personal entrepreneurship helped to prepare and conduct research in the target group. The results are presented and summarized in the following parts of the article.
\end{abstract}

Słowa kluczowe: osobowość przedsiębiorcza; przedsiębiorczość; przedsiębiorczość akademicka Key words: academic entrepreneurship; entrepreneurship; entrepreneurial personality 
Otrzymano: 11 listopada 2015

Received: 11 November 2015

Zaakceptowano: 20 marca 2016

Accepted: 20 March 2016

\section{Sugerowana cytacja/Suggested citation:}

Strojny, J., Chodorek, M. (2016). Badanie poziomu przedsiębiorczości indywidualnej na grupie studentów studiów magisterskich Wydziału Zarządzania Politechniki Rzeszowskiej. Przedsiębiorczość - Edukacja, 12, 416-425.

\section{Zagadnienie przedsiębiorczości - wybrane aspekty}

Zagadnienie przedsiębiorczości należy do bardzo popularnych obszarów badań naukowych. Jest analizowane z perspektywy wielu różnych dyscyplin, m.in. ekonomii, zarządzania, socjologii, psychologii. Dlatego też nie może dziwić liczba różnorodnych definicji samego pojęcia przedsiębiorczości. Niezależnie od przyjętych punktów widzenia należy się jednak zgodzić, że jest to z całą pewnością jeden z najistotniejszych fenomenów społecznych (Davidsson, 2003). Przedsiębiorczość $\mathrm{z}$ całą pewnością można traktować jako pewnego rodzaju cechę kardynalną człowieka. W takim ujęciu jest ona rozumiana jako „pewnego rodzaju wielowymiarowy zbiór cech (atrybutów), których zaistnienie daje podstawy do skutecznego i efektywnego zachowania się podmiotu i w polityce wewnętrznej, i w reakcjach na bodźce zewnętrzne" (Strojny, 2009: 29). Atrybuty indywidualne mogą się przekształcać w postawę osoby przedsiębiorczej wobec otoczenia. W określonych, sprzyjających warunkach atrybuty przedsiębiorcze uzewnętrzniają się w postaci określonego sposobu zachowania. Ukierunkowane jest ono na rozwój, podejmowanie ryzyka, wykorzystywanie okazji itd.

Przedsiębiorczość może być zatem specyficznym rodzajem aktywności człowieka, związanym z wykorzystywaniem szans niedostrzeganych przez innych (Piecuch, 2010). Opiera się ona na efektywnym wykorzystaniu w danych warunkach pomysłu innowacyjnego w celu osiągania określonych korzyści oraz przy uwzględnieniu związanego z tym ryzyka (Piecuch, 2010). Akceptacja ryzyka oznacza, że działanie zachodzi nie tylko w warunkach sprzyjających, lecz także utrudniających realizację celów (Wiatrak, 2003). Działanie przedsiębiorcze często utożsamiane jest z prowadzeniem małej firmy i innowacyjnością (Lemańska-Majdzik, Stawasz, 2007; Glinka, 2008; Fryczyńska, 2012; Kaczorowski, 2012). Niektórzy, jak np. P.F. Drucker (1992), wskazują, że jest to pewien sposób zarządzania, oparty na akceptacji ryzyka i determinacji w wykorzystywaniu szans rynkowych oraz innowacyjności (Drucker, 1998; 2004). Można zatem powiedzieć, że przedsiębiorczość to proces (Landstrom, 2001). Może on być rozumiany jako tworzenie albo identyfikacja szans oraz umiejętne ich wykorzystanie mimo ograniczonych zasobów (Timmons, 1990). Obejmuje szereg różnych etapów, które prowadzą od identyfikacji problemu, innowacyjnego pomysłu jego rozwiązania, przez zastosowanie nowatorskich rozwiązań zarządczych, aż po osiągnięcie sukcesu rynkowego (Adamczyk, 1996). Działanie przedsiębiorcze może cechować się różną dynamiką, na co zwraca uwagę L.H. Haber - identyfikuje on m.in. przedsiębiorczość: żywiołową, ewolucyjną czy systemową.

Zarówno w kontekście atrybutów indywidualnych, jak i określonych działań, zwłaszcza w obszarze gospodarczym, w literaturze wykorzystuje się pojęcie przedsiębiorcy. R. Cantillon dzieli uczestników rynku na dwie kategorie: osoby otrzymujące stałe wynagrodzenie, oraz tych, którzy generują niepewne zyski; w tej właśnie grupie znajdują się przedsiębiorcy 
(Cantillon, 1959). Na ten aspekt wskazuje także J.B. Say. Przedsiębiorca to osoba korzystająca z wiedzy w celu stworzenia produktu użytecznego dla uzyskania określonego zysku. (Say, 1960). Podobnym tropem podąża A. Smith - przedsiębiorcy w swoim działaniu kierują się dbałością o własny interes, który zapewnia zaspokojenie potrzeb odbiorcy (Smith, 1954). Dlatego charakteryzują się wysokim poziomem elastyczności w dostosowaniu się do potrzeb klientów (Piecuch, 2010). Przedsiębiorca to osoba twórcza, zdolna do niestandardowego działania (Baretto, 1989) czy wręcz do kreatywnej destrukcji. J. Schumpeter podkreśla fakt, że przedsiębiorca to nie zawód, lecz jedynie czasowo wykonywana czynność (Schumpeter, 1960). Jest on także gotowy do ponoszenia całkowitej odpowiedzialności za podejmowane działania i uzyskiwane efekty (Piecuch, 2010), a dodatkowo, dzięki innowacjom uzyskuje dużą skuteczność działania (Kirzner, 1984). Mając takie cechy, przedsiębiorca odgrywa rolę przywódcy, sterującego sprawnością działania przedsiębiorstwa (Majkut, 2014).

Z punktu widzenia niniejszego artykułu warto odnieść się także do zagadnienia przedsiębiorczości akademickiej. Od połowy poprzedniego stulecia w większym stopniu widoczny jest wpływ uczelni wyższych oraz innych instytucji naukowych na rozwój gospodarki i technologii. Chodzi tutaj m.in. o kształtowanie wiedzy dla potrzeb gospodarki. Dotyczy to np. dopływu innowacyjnych rozwiązań do rynku, rozwoju firm technologicznych, wzrostu samozatrudnienia pracowników naukowych czy studentów. W krajach rozwiniętych powszechne jest praktykowanie kreowania współpracy wiedzy i praktyki oraz wzbudzanie postaw przedsiębiorczych wśród pracowników naukowych. Typowy model ośrodka naukowego wzbogacony został o aspekt przedsiębiorczości. Złożoność współczesnych rynków oraz panujący na nich wysoki poziom konkurencji skłaniają do poszukiwania rozwiązań innowacyjnych. Stąd konieczność traktowania środowisk naukowych jako źródeł przedsiębiorczości (K.B. Matusiak, K. Matusiak, 2007).

Przedsiębiorczość akademicka jest to więc zjawisko, które „przełamuje schemat myślenia oparty na wyobrażeniu, że prowadzenie własnej firmy i próby komercyjne są sprzeczne z zasadami pracy badawczej, a tym samym niewłaściwe dla przedstawicieli środowiska naukowego" (Banerski, 2009). Jej podstawowe elementy, takie jak kreatywność, ambicja, odporność psychiczna, otwartość na otoczenie, dążenie do doskonałości, pasja itd. (Poznańska, 2014) wpisują się w atrybuty przedsiębiorczości. Ważne jest jednak to, że pojawiają się one w środowisku naukowym, co znacznie zwiększa rolę wiedzy oraz innowacyjności jako czynników wpływających na jakość działań.

Współcześnie aktywizacja sektora naukowego stanowi podstawowy czynnik wysokiego poziomu innowacyjności, czego wyrazem jest chociażby rozwój w ostatnich latach spółek odpryskowych spin-off/spin-out (Klimczuk-Kochańska, 2011). Powstają one na granicy pomiędzy środowiskiem akademickim a gospodarką i stanowią swoiste narzędzie transferu innowacji. Jak wskazują N. Nicolaou i S. Birley, tego typu podmioty mogą mieć charakter ortodoksyjny, hybrydowy i technologiczny (Nicolaou, Birley, 2003). Pierwszy z nich opiera się na podejściu, według którego podmiot w pełni korzysta $\mathrm{z}$ wiedzy wynalazcy (pracownika naukowego), a także transferowanej technologii. Model hybrydowy to taki, w którym jednostka bazuje na transferowanej technologii. Zaangażowani w projekt pracownicy naukowi mogą pozostać w ramach uczelni, sprawując jednocześnie funkcje doradcze i kontrolne w spółce. Ostatni typ spółek (technologiczny) charakteryzuje się natomiast wykorzystaniem przez podmiot technologii i wiedzy pochodzącej z uczelni, przy czym pracownicy naukowi nie mają żadnego kontaktu z nowo powstałą firmą. Mogą jedynie posiadać w niej określone udziały i świadczyć usługi doradcze. Podstawowym założeniem funkcjonowania form odpryskowych 
jest transfer nowych technologii z nauki na rynek (gospodarki). Aby działania w ramach przedsiębiorczości akademickiej realizowane były skutecznie, potrzebne jest funkcjonowanie systemu instytucji tworzonych przez sektor nauki, instytucje rządowe, firmy, instytucje okołobiznesowe itd. (Cichocki, 2011).

W Polsce istnieje wciąż szereg barier hamujących rozwój przedsiębiorczości akademickiej. Mają one charakter popytowy, prawny oraz finansowy (Klimczuk-Kochańska, 2011). Znacznie mniej istotne okazały się bariery kompetencyjne, mentalno-kulturowe czy organizacyjne. Pomimo wskazanych korzyści wynikających ze współpracy naukowo-biznesowej w przypadku małych firm spin-off czynnikiem hamującym ich ekspansję rozwojową jest brak wsparcia ze strony jednostek otoczenia biznesowego. Problem istnieje również po stronie instytucji naukowych, które w praktyce nie wspierają tego typu aktywności wśród pracowników czy studentów. Badania, przeprowadzone na zlecenie Polskiej Agencji Rozwoju Przedsiębiorczości (PARP), wskazują na konieczność wprowadzenia zmian w całościowym systemie funkcjonowania uczelni, głównie w zakresie oferty programowej, infrastruktury wsparcia przedsiębiorczości. Do najistotniejszych elementów zaliczono (Banerski, 2009):

- poprawę oferty programowej o moduły związane z tematyką przedsiębiorczości, innowacji, komercjalizacji badań naukowych,

- promowanie przedsiębiorczości akademickiej przez wdrażanie na uczelni profesjonalnych programów szkoleniowych, dostosowanych do uwarunkowań prawnych, instytucjonalnych, społecznych i ekonomicznych,

- wykorzystywanie metod nauczania, opartych na doświadczeniu,

- rozwój infrastruktury przedsiębiorczości akademickiej poprzez przygotowywanie zespołów zarządzających i usług dla nowo tworzonych firm,

- wdrożenie mechanizmów zarządzania własnością intelektualną.

W kontekście przeprowadzonej analizy zdefiniowano ciekawy aspekt przedsiębiorczości, jakim jest przedsiębiorczość indywidualna studentów. Łączy on wszystkie analizowane wyżej wymiary, odnosząc się zarówno do atrybutów osobowości, jak i do potencjalnego ich przełożenia na prowadzenie działalności gospodarczej. Badania osadzono w środowisku akademickim, co dodatkowo podnosi potencjalną użyteczność prowadzonego badania. Jak bowiem podkreślono w analizie, przedsiębiorczość akademicka, a zatem również studentów, stanowić powinna fundament współczesnej gospodarki, zapewniając efektywny transfer wiedzy do społeczeństwa i gospodarki.

\section{Założenia badawcze}

Rozwijając wskazane wyżej zagadnienie, sformułowano ogólne założenia badawcze. W pierwszej kolejności postawiono pytanie główne:

PG. Na jakim poziomie kształtuje się przedsiębiorczość indywidualna badanych studentów?

Oczywiście tak postawiony problem wymaga uszczegółowienia w postaci problematyki badawczej. Obejmuje ona następujące pytania:

PS.1. Jakie atrybuty budują przedsiębiorczość indywidualną badanych studentów?

PS.2. Jak duże jest natężenie przedsiębiorczości indywidualnej oraz poszczególnych jej atrybutów w badanej grupie studentów?

PS.3. Czy płeć badanych studentów wpływa na natężenie przedsiębiorczości indywidualnej oraz jej atrybutów? 
Odpowiadając na pierwsze z postawionych pytań, odwołano się do modelu osobowości przedsiębiorczej proponowanego przez J. Strojnego (2009). Obejmuje on następujące wymiary:

- W.1: potrzeby osiągnięć, obejmujące potrzeby: sukcesu, wysokiej pozycji społecznej, władzy, pieniędzy oraz pracy.

- W.2: sterowność wewnętrzną, która warunkowana jest przez: wysoką samoocenę, samodzielność, niezależność sądu i opinii, odpowiedzialność, optymizm, zaufanie do innych ludzi, gotowość do zmian oraz myślenie długookresowe.

- W.3: zdolności intelektualne, w tym: wiedzę, zainteresowanie otoczeniem, horyzont zainteresowań, zdobywanie wiedzy, inteligencję, kreatywność, uzdolnienia.

Analizie poddano dobraną celowo grupę 100 studentów studiów magisterskich Wydziału Zarządzania Politechniki Rzeszowskiej w okresie od początku maja do końca czerwca 2015 r. Wybór tej grupy podyktowany jest faktem kończenia przez tych studentów studiów i ich wchodzeniem w niedługiej perspektywie na rynek pracy. Badanie miało pozwolić ocenić, czy poziom przedsiębiorczości indywidualnej stanowić będzie czynnik istotnie determinujący start zawodowy. W badaniu wykorzystano kwestionariusz osobowości przedsiębiorczej autorstwa J. Strojnego (2009). Jest on przeznaczony do pomiaru osobowości przedsiębiorczej według przedstawionego wyżej modelu. Zastosowane narzędzie pozwoliło na ocenę natężenia badanego zjawiska na poziomie ogólnym (osobowość przedsiębiorcza), wymienionych trzech wymiarów oraz składających się na nie parametrów. Zastosowano w nim skalę Likerta (od 1 do 5), pytając o to, na ile poszczególne stwierdzenia odnoszą się do badanej osoby. Tak zebrane informacje zagregowano do poziomu indeksów. W badaniu zastosowano trzy poziomy indeksów: indeks osobowości przedsiębiorczej (1 indeks), indeksy wymiarów osobowości przedsiębiorczej (3 indeksy), indeksy parametrów dla każdego z wymiarów osobowości przedsiębiorczej (20 indeksów). Aby obliczyć wartość indeksu, należy zastosować następujący wzór:

$$
I=\frac{\sum_{i=1}^{n} S_{i}-N S_{\min }}{N\left(S_{\max }-S_{\min }\right)} \cdot 100
$$

gdzie:

I - wartość indeksu

$\mathrm{S}_{\mathrm{i}}$ - wartość składowej indeksu

$\mathrm{S}_{\min }$ - najniższa możliwa wartość składowej indeksu

$\mathrm{N}$ - liczba składowych indeksu

$\mathrm{R}$ - rozstęp $\left(\mathrm{R}=\mathrm{S}_{\max -} \mathrm{S}_{\min }\right)$

Indeksy przyjmują wartość standaryzowaną z przedziału $<0 ; 100>$. W badaniu natężenia wartości cech zastosowano następujące przedziały: niskie natężenie cechy - wartość indeksu w przedziale $<0 ; 33,33>$, średnie natężenie cechy - wartość indeksu w przedziale $<33,33$; $66,67>$ oraz wysokie natężenie cechy - wartości indeksu mieszczą się w przedziale <66,67; $100>$. Zbudowane indeksy skonfrontowano także z informacją o płci badanych studentów oraz ich miejscu zamieszkania. Wykorzystano tutaj analizę średnich, obliczając je dla każdego przedziału zmiennej determinującej. 
Analiza przedsiębiorczości indywidualnej studentów studiów magisterskich Wydziału Zarządzania PRz

Przedsiębiorczość indywidualna w badanej grupie studentów kształtuje się na poziomie średnim. Wartość średnia indeksu głównego wynosi 60,52 pkt. Warto podkreślić, że natężenie poszczególnych wymiarów jest bardzo zrównoważone. Wartości indeksów kształtują się bowiem w granicach od 58,93 pkt dla potrzeb osiągnięć do 62,23 - w przypadku zdolności intelektualnych (ryc. 1).

Ryc. 1. Wymiary przedsiębiorczości indywidualnej - wartość indeksów

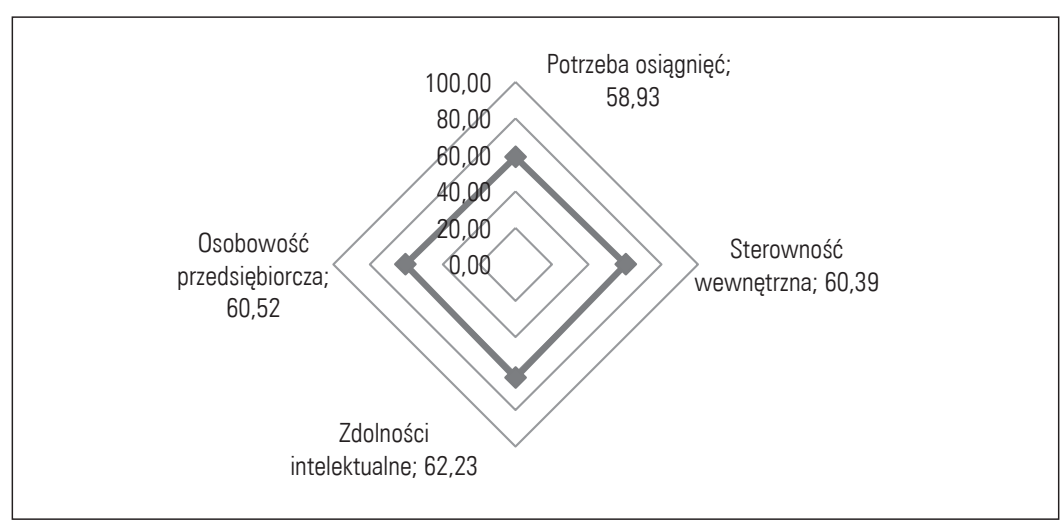

Źródło: opracowanie własne

Pierwszy z badanych wymiarów przedsiębiorczości indywidualnej dotyczy potrzeb osiągnięć. Uwzględniono tu szereg z nich - potrzebę sukcesu, pozycji społecznej, władzy, pieniędzy czy pracy. Różnice natężenia poszczególnych potrzeb nie są zbyt duże w badanej próbie. Najsłabiej akcentowana jest potrzeba sukcesu - 56,05 pkt, zaś najmocniej potrzeba pieniędzy 62,38 pkt (ryc. 2).

Ryc. 2. Parametry wymiaru związanego z potrzebami osiągnięć - wartość indeksów

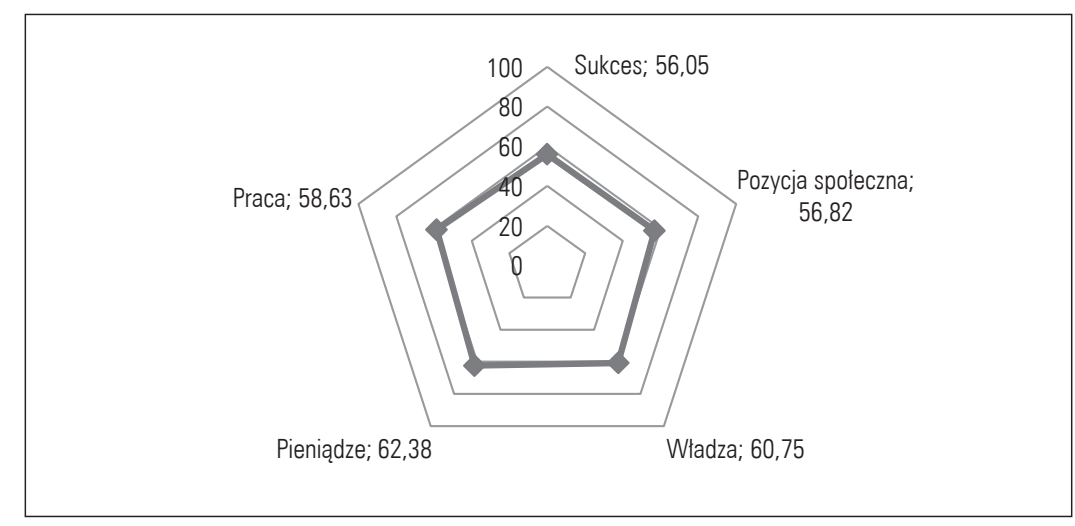

Źródło: opracowanie własne 
Kolejny wymiar - sterowność wewnętrzna - determinowany jest przez wiele różnych cech, które wpływają na tego typu postawę (ryc. 3). Charakterystyczne jest to, że w badanej grupie najsłabiej wypada zaufanie do innych $(45,25$ pkt). Ten parametr miał najniższe natężenie również w badaniach przedsiębiorców (Strojny, 2009). Natomiast najbardziej charakterystyczną cechą badanej grupy jest gotowość do zmian (68 pkt). Warto podkreślić, że tego typu cecha idzie w parze z myśleniem długofalowym $(65,97$ pkt).

Ryc. 3. Parametry wymiaru związanego ze sterownością wewnętrzną - wartość indeksów

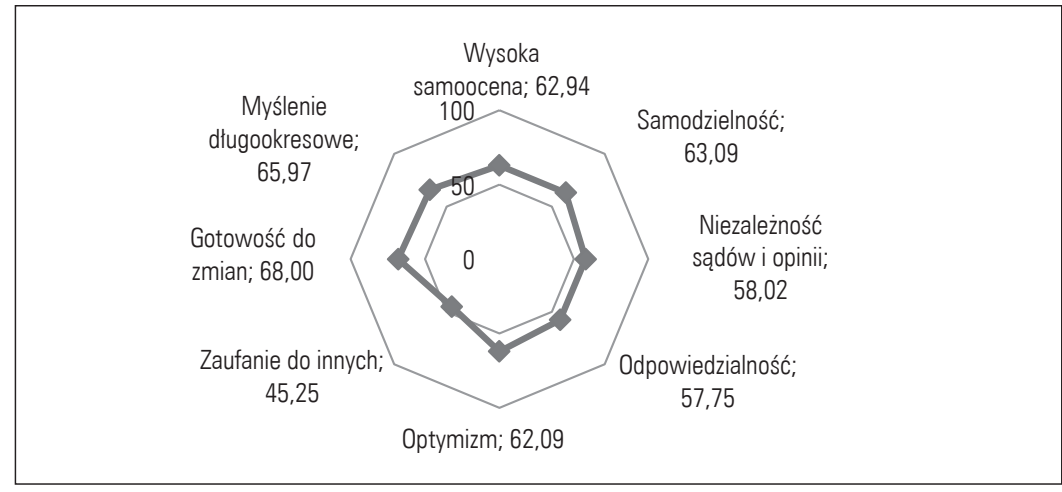

Źródło: opracowanie własne

Ostatni wymiar związany jest ze zdolnościami niezbędnymi do uruchomienia wielu rodzajów aktywności (ryc. 4). Studenci charakteryzują się przede wszystkim wysokim poziomem wiedzy (70,20 pkt) oraz zainteresowaniem otoczeniem (69,91 pkt). Najsłabiej natomiast wypadają różnego rodzaju uzdolnienia (51,82 pkt). Inteligencja i kreatywność są zaś na poziomie 61-63 pkt.

Ryc. 4. Parametry wymiaru związanego ze zdolnościami intelektualnymi - wartość indeksów

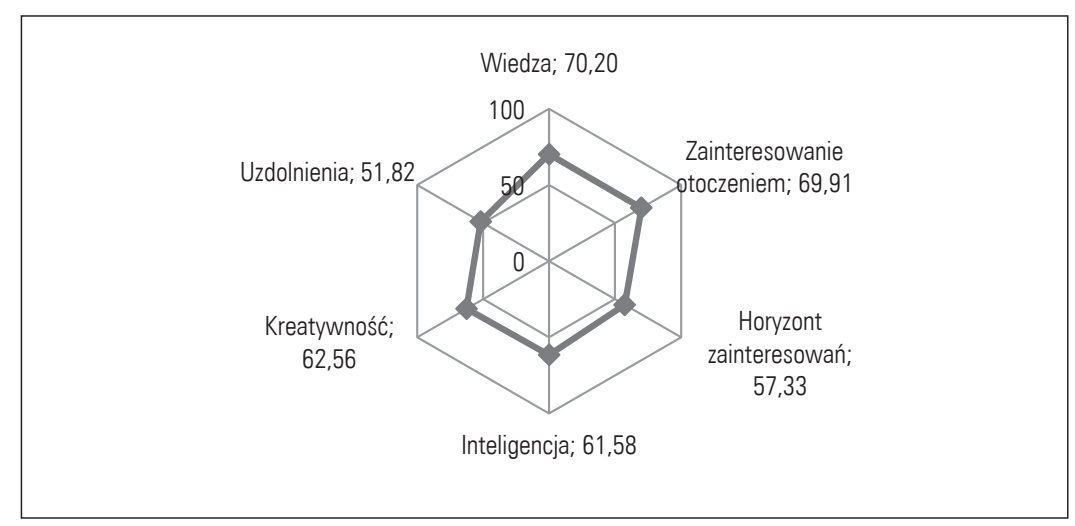

Źródło: opracowanie własne 
Badając różnice pomiędzy kobietami i mężczyznami, zidentyfikowano składowe osobowości przedsiębiorczej, które różnicują te dwie grupy studentów. Jako kryterium przyjęto różnicę na poziomie min. 4 pkt, skupiając się na poziomie najbardziej szczegółowych indeksów. Kobiety i mężczyźni najbardziej różnią się pod względem horyzontu zainteresowań oraz zaufania do innych. Mężczyźni wyróżniają się znacznie wyższym natężeniem parametru odnoszącego się do horyzontu zainteresowań (63,80 pkt wobec 54,15 pkt). Zaś kobiety wykazują znacznie wyższe zaufanie do innych (48,43 pkt wobec 38,79 pkt). W przypadku pozostałych parametrów (władza, pieniądze, inteligencja, wiedza, potrzeba sukcesu czy kreatywność) wyższe natężenie zanotowano w przypadku mężczyzn (ryc. 5).

Ryc. 5. Różnice (wartość wskaźnika dla mężczyzn - wartość wskaźnika dla kobiet) między oceną parametrów przedsiębiorczości indywidualnej kobiet i mężczyzn

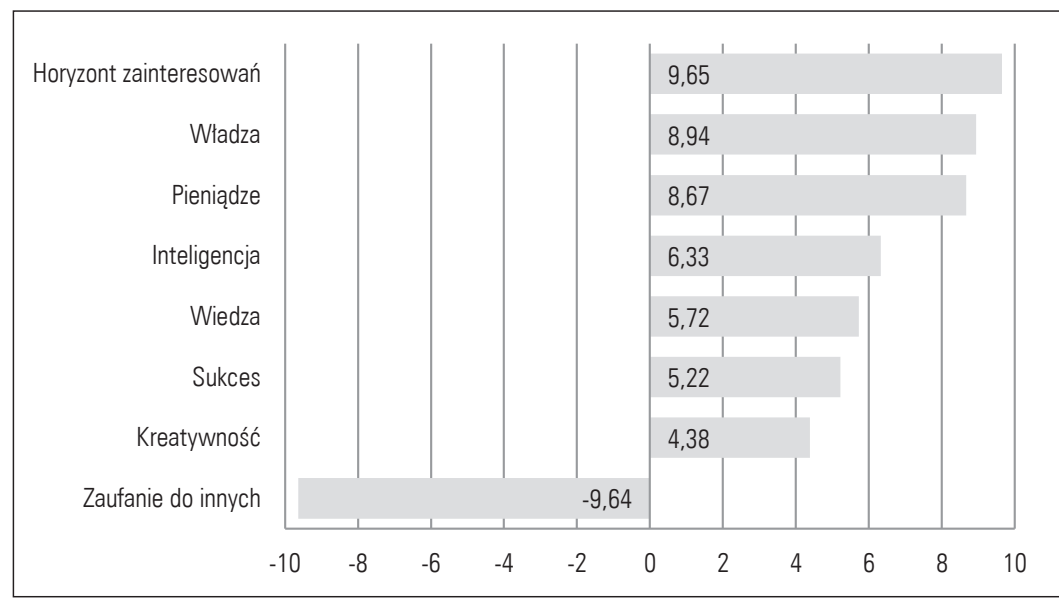

Źródło: opracowanie własne

Różnice pomiędzy kobietami i mężczyznami zaobserwowano również na poziomie wymiarów osobowości. Wyższe natężenie odnotowano szczególnie w przypadku potrzeb osiągnięć. Mężczyźni mają je nieco bardziej wyraziste - 61,70 pkt wobec 57,54 pkt. Natomiast na poziomie indeksu głównego różnice nie są już tak znaczące. Obserwuje się bowiem niewielką przewagę natężenia osobowości przedsiębiorczej w grupie mężczyzn w stosunku do grupy kobiet - 61,65 pkt wobec 59,45 pkt.

\section{Podsumowanie i wnioski}

Przeprowadzona analiza jest kolejną próbą weryfikacji użyteczności kwestionariusza osobowości przedsiębiorczej autorstwa J. Strojnego. Badania przeprowadzone na grupie 100 studentów pozwalają na przedstawienie głównej sugestii metodologicznej. Dotyczy ona zasad konstruowania wskaźników. Rozważać można przekształcenie stosowanego modelu osobowości przedsiębiorczej w model hierarchiczny AHP (Analytic Hierarchy Process). Pozwoli to na określenie elementów priorytetowych z punktu widzenia przedsiębiorczości poprzez wyznaczenie ich wag. 
Jeśli chodzi o uzyskane efekty poznawcze, to z całą pewnością należy podkreślić, że studenci z badanej grupy nie wybijają się poziomem przedsiębiorczości. Natężenie badanych atrybutów znajdowało się zazwyczaj w granicach poziomu średniego, choć raczej bliżej górnego ograniczenia. W przypadku niektórych parametrów zanotowano poziomy z przedziału wysokiego natężenia. Ciekawym, choć nie nowym spostrzeżeniem jest także nieznaczna przewaga mężczyzn nad kobietami w zakresie natężenia cech przedsiębiorczych. Nie jest to zbyt mocno widoczne na poziomie indeksu głównego, ale już na poziomie niektórych wymiarów, a szczególnie parametrów różnice są znaczące.

Rozwijając przedstawiony w badaniu temat, należy przede wszystkim podkreślić konieczność prowadzenia badań w kierunku innych grup składających się na społeczność akademicką. Szczególnie ciekawe byłoby przebadanie pracowników akademickich. Jest to jeden z możliwych scenariuszy przyszłych badań w tym zakresie.

\section{Literatura}

References

Adamczyk, W. (1996). Przedsiębiorczość: Próba systematyzacji. Przegląd Organizacji, 2, 13-18.

Banerski, G. (2009). Przedsiębiorczość akademicka. Raport z badania. Warszawa: PARP.

Barretto, H. (1989). The entrepreneuer in microeconomy theory. London: Rouledge.

Cichocki, T. (2011). Osobowość przedsiębiorcza. W: A. Pomykalski (red.), Przedsiębiorczość akademicka. Rzeszów: INNpuls, 9-26.

Cantillon, R. (1959). Essai sur la nature du commerce en general. London: The Royal Economic Society.

Davidsson, P. (2003). The domain of entrepreneurship research: Some suggestions. W: J.A. Katz, D.A. Shepherd (red.), Advances in entrepreneurship, firm emergence and growth, t. 6. Greenwich: JAI Press, 315-372.

Drucker, P.F. (1998). Praktyka zarządzania. Kraków: Wydawnictwo Akademii Ekonomicznej.

Drucker, P.F. (2004). Natchnienie i fart, czyli innowacja i przedsiębiorczość. Warszawa: Studio Emka.

Fryczyńska, M. (2012). Istota i uwarunkowania przedsiębiorczości. W: B. Jamka (red.), Potencjał ludzki w rozwoju przedsiębiorczości indywidualnej i korporacyjnej. Warszawa: Difin, 59-78.

Glinka, B. (2008). Kulturowe uwarunkowania przedsiębiorczości w Polsce. Warszawa: PWE.

Kaczorowski, P. (2012). Samozatrudnienie jako forma rozwoju przedsiębiorczości w województwie łódzkim - ocena dotychczasowego stanu, bariery i perspektywy. W: E. Kwiatkowski (red.), Popytowe i podażowe aspekty rozwoju kapitału ludzkiego w regionie łódzkim. Łódź: Wydawnictwo Naukowe UŁ, 233-260.

Kirzner, I.M. (1984). The entrepreneurial process. W: C.A. Kent (red.), The environment for entrepreneurship. Lexington: Lexington Books, 41-58.

Klimczuk-Kochańska, M. (2011). Bariery rozwoju przedsiębiorczości akademickiej na przykładzie podlaskich uczelni. Zeszyty Naukowe WSEI, 3, 73-98.

Landstrom, H. (2010). Pioneers in entrepreneurship and small business research. New York: Springer.

Lemańska-Majdzik, A., Stawasz, E. (2007). Samozatrudnienie, aktywne formy przeciwdziałania bezrobociu - doświadczenia krajowe i zagraniczne. W: H. Skłodowski, E. Stawasz (red.), Psychologiczne wyznaczniki poszukiwania pracy $i$ samozatrudnienia $w$ regionach zmarginalizowanych. Łódź: Wydawnictwo Naukowe UŁ, 29-42.

Majkut, R. (2014). Przedsiębiorczość w świetle uwarunkowań interdyscyplinarnych. Warszawa: Wydawnictwo CeDeWu.

Matusiak, K.B., Matusiak, M. (2007). Pojęcie i ekonomiczne znaczenie przedsiębiorczości akademickiej. Zeszyty Naukowe Uniwersytetu Szczecińskiego, 453, 155-165.

Nicolaou, N., Birley, S. (2003). Academic networks in trichotomous categorisation of university spinouts. Journal of Business Venturing, 18, 333-359. 
Piecuch, T. (2010). Przedsiębiorczość. Podstawy teoretyczne. Warszawa: C.H. Beck.

Poznańska, K. (2014). Przedsiębiorczość akademicka - cechy i znaczenie w gospodarce światowej i polskiej. Zeszyty Naukowe Uniwersytetu Ekonomicznego w Katowicach, 183, 164-172.

Say, J.B. (1960). Traktat o ekonomii politycznej. Warszawa: PWN.

Schumpeter, J. (1960). Teoria rozwoju gospodarczego. Warszawa: PWN.

Smith, A. (1954). Badania nad natura i przyczynami bogactwa narodów. Warszawa: PWN.

Strojny, J. (2009). Zarządzanie przedsiębiorczościa w małej i średniej firmie. Rzeszów: Oficyna Wydawnicza Politechniki Rzeszowskiej.

Timmons, J.A. (1990). New venture creation. Boston: Irwin.

Wiatrak, A.P. (2003). Pojęcie przedsiębiorczości, jej cele i rodzaje. W: K. Jaremczuk (red.), Uwarunkowania rozwoju przedsiębiorczości - szanse i zagrożenia. Tarnobrzeg: Wydawnictwo PWSZ, 26-38.

Jacek Strojny, ekonomista, dr nauk ekonomicznych w zakresie nauk o zarządzaniu, adiunkt w Katedrze Ekonomii Wydziału Zarządzania Politechniki Rzeszowskiej, pełnomocnik dziekana ds. projektów rozwojowych i komercjalizacji badań. Specjalizuje się w problematyce implementacji metod i technik zarządzania w przedsiębiorstwach i jednostkach administracji publicznej, zarówno na poziomie zarządzania strategicznego, jak i operacyjnego. Jest autorem kilkudziesięciu publikacji dotyczących przedsiębiorczości i innowacji, rozwoju regionalnego i lokalnego oraz zarządzania projektami. Koordynował projekty wdrożenia innowacyjnych systemów zarządzania w kilkudziesięciu przedsiębiorstwach i samorządach. Jest także autorem strategii rozwoju lokalnego na poziomie gminnym i powiatowym.

Jacek Strojny, economist, $\mathrm{PhD}$, Assistant Professor in the Department of Economics, Faculty of Management, Rzeszow University of Technology, The Dean's Plenipotentiary for Development and Commercialization. Specializes in methods and techniques of implementation in companies and public administration institutions on the strategic and operational level. The author of several dozen publications related to entrepreneurship, innovations, local and regional development and project management as well. He was a coordinator of many innovative implantation projects in companies and public institutions. He is the author of strategic documents prepared on the municipality and district level.

\section{Adres/Address:}

Politechnika Rzeszowska

al. Powstańców Warszawy 12

35-959 Rzeszów, Polska

e-mail: jstrojny@prz.edu.pl

Michał Chodorek, absolwent Politechniki Rzeszowskiej na Wydziale Zarządzania. Ukończył jako najlepszy uczeń Technikum Ekonomiczne w Opatowie. Aktywny działacz w kole naukowym Ekobiznes. Trzykrotny konferansjer Ogólnopolskich i Międzynarodowych Zawodów Robotów ROBO-motion. Zainteresowania autora skupiają się wokół zagadnień związanych z psychologią zarządzania i przedsiębiorczością.

Michał Chodorek, graduate of the Rzeszów University of Technology at the Faculty of Management, professional manager specialization. Graduate and best student of the Technical Economical School in Opatow. An activist in the scientific circle Ekobiznes. Three-time announcer at the Nationwide and International Robotics Competition ROBO-motion. His interests are focused on the psychology of management and entrepreneurship.

\section{Adres/Address:}

Politechnika Rzeszowska

al. Powstańców Warszawy 12

35-959 Rzeszów, Polska

e-mail: ertw46@wp.pl 